(c) American Dairy Science Association, 2004.

\title{
Biohydrogenation, Duodenal Flow, and Intestinal Digestibility of Trans Fatty Acids and Conjugated Linoleic Acids in Response to Dietary Forage:Concentrate Ratio and Linseed Oil in Dairy Cows
}

\author{
J. J. Loor, ${ }^{\star}$ K. Ueda,† A. Ferlay, Y. Chilliard, and M. Doreau \\ Unité de Recherches sur les Herbivores, INRA-Theix, \\ 63122 St.- Genès Champanelle, France
}

\begin{abstract}
Duodenal flows of hydrogenation intermediates in response to changes in dietary forage:concentrate ratio $(\mathrm{F}: \mathrm{C})$ and linseed oil were evaluated using 4 lactating Holstein cows fed a low (65:35 forage to concentrate) or high (35:65) concentrate diet without (LC, HC) added oil or with linseed oil (LCO, HCO) at $3 \%$ of DM. A $4 \times$ 4 Latin square design was implemented for $5 \mathrm{wk}$. Lower hydrogenation of 18:2n-6 and 18:3n-3 was observed with HC, but it increased with LCO or HCO. Duodenal flow of total conjugated linoleic acids (CLA) increased by 1.40 (LCO) to 3.01 (HCO) $\mathrm{g} / \mathrm{d}$ with linseed oil. This response was associated with greater flows of cis9,trans11- $(+0.21$ to $+0.55 \mathrm{~g} / \mathrm{d})$, trans11,cis $13-(+0.33$ to +0.36$)$, trans 11 ,trans $13-(+1.01$ to $+1.15 \mathrm{~g} / \mathrm{d})$, and trans,transCLA (+0.12 to $+0.72 \mathrm{~g} / \mathrm{d})$. Trans 10 , cis12-CLA flow averaged $0.08 \mathrm{~g} / \mathrm{d}$ and was not affected by $\mathrm{F}: \mathrm{C}$ or oil. trans 11,cis15-18:2 flow increased by 8.5 (LCO) to 62 (HCO) $\mathrm{g} / \mathrm{d}$ in response to linseed oil. Total trans-18:1 flow was $37 \mathrm{~g} / \mathrm{d}$ in cows fed LC and increased to $81 \mathrm{~g} / \mathrm{d}$ with HC. Feeding oil increased total trans-18:1 to the greatest extent with HCO. Flow of trans10-18:1 was lower with LC than with HC (1.46 vs. 20 g/d). Linseed oil increased trans11-18:1 flow by 40 (LCO) to $113 \mathrm{~g} / \mathrm{d}$ (HCO). Feeding LCO and HCO also increased flows of trans6+7+8-, trans13+14-, trans15-, and trans16-18:1. Apparent intestinal digestibility of trans-18:1 isomers was largely unaffected by concentrate level and ranged between 67 and 95\%. Linseed oil increased digestibility of nearly all isomers by 3 to 16 percentage units. Digestibility of cis9,trans11-CLA was greater in cows fed HC (55\%) compared with cows fed LC (32\%) and was not affected by linseed oil. Data suggest that high concen-
\end{abstract}

\footnotetext{
Received July 10, 2003.

Accepted April 27, 2004.

Corresponding author: M. Doreau; e-mail: doreau@clermont. inra.fr.

*Present address: Department of Animal Sciences, University of Illinois, 206 ERML, Urbana, IL 61801 (jloor@uiuc.edu).

$\dagger$ Present address: Graduate School of Agriculture, Hokkaido University, Sapporo, 060-8589 Japan.
}

trate diets enhanced ruminal outflow of trans10-18:1. We provide initial in vivo evidence that supplemental 18:3n-3 is hydrogenated to trans 11 , cis $15-18: 2$, trans $11-$ 18:1, trans $13+14-18: 1$, trans $15-18: 1$, trans $6+7+8-18: 1$, and trans 16-18:1 primarily.

(Key words: hydrogenation, linseed oil, digestion, trans fatty acid)

Abbreviation key: CLA = conjugated linoleic acid, $\mathbf{F}: \mathbf{C}=$ forage:concentrate ratio, $\mathbf{H C}=$ high concentrate $\operatorname{diet}(35: 65 \mathrm{~F}: \mathrm{C}$ ratio), $\mathbf{H C O}=\mathrm{HC}$ with linseed oil at $3 \%$ of $\mathrm{DM}, \mathbf{L C}=$ low concentrate $\operatorname{diet}(65: 35 \mathrm{~F}: \mathrm{C}$ ratio), LCO = LC with linseed oil at $3 \%$ of DM.

\section{INTRODUCTION}

Feeding high concentrate diets to dairy cows often reduces milk fat production (Doreau et al., 1999). Biohydrogenation of polyunsaturated fatty acids in the rumen is reduced when high concentrate diets are fed (Doreau and Ferlay, 1994; Kalscheur et al., 1997). This response is associated with shifts in bacterial populations (Latham et al., 1972), causing a reduction in the conversion of trans-18:1 isomers to 18:0 (Van Nevel and Demeyer, 1996).

Amounts of biohydrogenation intermediates produced in the rumen influence their concentrations in tissues or milk (Demeyer and Doreau, 1999; Chilliard et al., 2000). In cows fed high concentrate diets without (Piperova et al., 2002) or with (Griinari et al., 1998; Piperova et al., 2000) vegetable oils rich in linoleic acid, trans 10 18:1 concentration in milk fat was greater than trans1118:1. Cis9,trans11-, trans7,cis9-, trans8,cis10-, and trans10,cis 12-18:2 concentrations in milk fat also were altered by changing forage:concentrate (F:C) ratio (Piperova et al., 2000, 2002). Vaccenic acid (trans11-18:1) and conjugated linoleic acids (CLA) (cis9,trans11-18:2 and trans 10,cis12-18:2) in meat and milk are examples of biohydrogenation intermediates that may have beneficial implications in human health. Thus, additional knowledge concerning microbial biohydrogenation of unsaturated fatty acids in the rumen may benefit the nutrition and health of humans. 
Table 1. Ingredient and chemical composition of diets.

\begin{tabular}{|c|c|c|c|c|}
\hline & \multicolumn{4}{|c|}{ Diet $^{1}$} \\
\hline & $\mathrm{LC}$ & LCO & $\mathrm{HC}$ & $\mathrm{HCO}$ \\
\hline \multicolumn{5}{|l|}{ Ingredient, \% of DM } \\
\hline Grass hay, long cut & 65.0 & 65.0 & 35.0 & 35.0 \\
\hline Soybean meal & 7.0 & 17.0 & 0.0 & 5.0 \\
\hline Linseed oil & 0.0 & 3.0 & 0.0 & 3.0 \\
\hline \multicolumn{5}{|l|}{ Concentrate mixture } \\
\hline Ground wheat & 14.0 & 7.5 & 32.4 & 28.4 \\
\hline Rapeseed meal & 5.0 & 2.6 & 11.6 & 10.2 \\
\hline Sunflower meal & 4.1 & 2.2 & 9.7 & 8.5 \\
\hline Wheat bran & 2.8 & 1.5 & 6.5 & 5.8 \\
\hline Wet beet molasses & 0.6 & 0.3 & 1.3 & 1.1 \\
\hline Distiller's bran & 0.6 & 0.3 & 1.3 & 1.1 \\
\hline Limestone & 0.7 & 0.4 & 1.6 & 1.3 \\
\hline Sodium chloride & 0.1 & 0.1 & 0.3 & 0.3 \\
\hline Mineral-vitamin $\operatorname{mix}^{2}$ & 0.1 & 0.1 & 0.3 & 0.3 \\
\hline \multicolumn{5}{|l|}{ Composition, \% of DM } \\
\hline $\mathrm{OM}$ & 91.5 & 91.7 & 92.3 & 92.5 \\
\hline $\mathrm{CP}$ & 16.9 & 19.1 & 17.4 & 18.2 \\
\hline NDF & 44.5 & 43.3 & 33.7 & 32.8 \\
\hline $\mathrm{ADF}$ & 24.7 & 24.1 & 18.3 & 17.9 \\
\hline Starch & 11.1 & 6.6 & 23.9 & 21.1 \\
\hline Total fatty acids & 1.6 & 4.7 & 1.9 & 5.1 \\
\hline \multicolumn{5}{|c|}{ Fatty acid profile, g/100 g total fatty acids } \\
\hline $12: 0$ & 0.23 & 0.07 & 0.11 & 0.04 \\
\hline $14: 0$ & 0.64 & 0.24 & 0.38 & 0.17 \\
\hline 16:0 & 21.7 & 10.8 & 17.8 & 10.1 \\
\hline $\operatorname{cis} 9-16: 1$ & 0.65 & 0.23 & 0.58 & 0.25 \\
\hline 18:0 & 2.43 & 3.43 & 2.06 & 3.15 \\
\hline $\operatorname{cis} 9-18: 1$ & 17.9 & 15.5 & 29.1 & 20.6 \\
\hline $18: 2 n-6$ & 30.7 & 20.2 & 36.0 & 23.0 \\
\hline $18: 3 n-3$ & 25.8 & 49.6 & 14.0 & 42.6 \\
\hline
\end{tabular}

Postruminal flows of trans-18:1 and CLA isomers were previously reported in lactating cows fed diets with 2 different $\mathrm{F}: \mathrm{C}$ but without lipid supplementation (Piperova et al., 2002). Interactions between F:C and unsaturated oils likely alter intestinal flows of hydrogenation intermediates. The primary objective of this study was to evaluate flows of cis and trans isomers of 18:1 and 18:2 during 5 wk of feeding high concentrate diets alone or in combination with linseed oil in lactating cows.

\section{MATERIALS AND METHODS}

\section{Animals and Diets}

Four peak lactation multiparous Holstein cows (55 to 87 DIM) were used in a $4 \times 4$ Latin square design with factorial arrangement of treatments during 45 -wk periods to evaluate responses to feeding diets (Table 1) with a low $(\mathrm{F}: \mathrm{C}=65: 35)$ or high (F:C 35:65) concentrate without (LC, HC) added oil or with linseed oil (Huilerie Van de Putte, Mouscron, Belgium) (LCO, HCO) supplemented at $3 \%$ of DM. Concentration (\% of total fatty acids) of 18:3n-3, 18:2n-6, cis9-18:1, 18:0, and 16:0 in linseed oil was $59,15,16,4$, and $6 \%$, respectively. During a 3 -wk adaptation before the study, cows were fed a diet with equal amounts of forage and concentrate plus linseed oil at $1.5 \%$ of DM. Subsequently, the assigned diets were fed for $5 \mathrm{wk}$ during each experimental period. The first $5 \mathrm{~d}$ of each period were used as a transition between treatments. Cows were housed in a tie stall barn during the experiment. The concentrate mixture with or without linseed oil was prepared daily and, along with the forage, was offered in equal amounts at 0900, 1330, and $1700 \mathrm{~h}$ for ad libitum consumption. Forage and concentrate refusals were weighed once daily, and quantities offered the following day were adjusted to maintain the desired F:C. Cows were milked at 0600 and $1700 \mathrm{~h}$. The experimental protocol was approved by the Institut National de la Recherche Agronomique Animal Care and Use Committee. All experimental procedures were conducted in accordance with French Guidelines concerning the use of experimental animals including animal welfare (Anonymous, 1988). 


\section{Sampling, Measurements, and Analyses}

Protocols for duodenal sample collection and analyses and data on OM, fiber, DM flows, and digestibility are presented in Ueda et al. (2003). Intake of DM, milk production, composition, and fatty acid profiles in milk fat are presented in Loor et al. (2002a). Briefly, DM digestibility was measured by total collection during the last $6 \mathrm{~d}$ of each period, and duodenal DM flow was assessed using $\mathrm{YbCl}_{3}$ and polyethylene glycol. Both marker solutions (400 mg $\mathrm{YbCl}_{3} / \mathrm{L}, 65 \mathrm{~g}$ polyethylene glycol/L) were continuously infused $(100 \mathrm{~mL} / \mathrm{h})$ into the rumen during the last $5 \mathrm{~d}$ of each period beginning at $0900 \mathrm{~h}$. Duodenal digesta (solid and liquid phases) samples (250 $\mathrm{mL}$ ) from each cow were collected on d 26, 27, and 28 of each period to represent 3 -h intervals within a 24 -h period. A total of 16 samples of duodenal digesta were collected during the 3-d period. Samples for fatty acid analysis were obtained after reconstitution (based on duodenal DM flow) of the appropriate amount of residue and filtrate. Methods for separation of residue and filtrate and calculation of the reconstitution factor are presented in Ueda et al. (2003).

Fatty acids in linseed oil were directly methylated by in situ transesterification with $2 \mathrm{~mL}$ of $0.5 \mathrm{~N} \mathrm{NaOCH}_{3}$ at $50^{\circ} \mathrm{C}$ for $10 \mathrm{~min}$. Fatty acids in grass hay, soybean meal, and the concentrate mixture were methylated as described by Sukhija and Palmquist (1988). Fatty acids in duodenal digesta and feces were methylated essentially as described by Sukhija and Palmquist (1988) with modifications. Chloroform was chosen as the extracting solvent, and volume used was increased from 2 to 6 $\mathrm{mL}$. The concentration of methanolic-HCl was decreased from $10 \%$, as originally described, to $6.5 \%$, and volume used was increased from 3 to $9 \mathrm{~mL}$. Thus, the ratio of extracting solvent to methylation reagent was the same as in Sukhija and Palmquist (1988). Incubation time was increased from 2 to $2.5 \mathrm{~h}$, and temperature was reduced from 80 to $65^{\circ} \mathrm{C}$. Tubes were continuously checked for leaks during incubation and were repeated if gross leaks could not be controlled. These modified conditions minimized isomerization of cis9,trans11-18:2 and trans10,cis12-18:2 (Kramer and Zhou, 2001; Park et al., 2001), while ensuring complete recovery of total fatty acids in samples (Kramer and Zhou, 2001). In all cases, fatty acid methyl esters were recovered in $1 \mathrm{~mL}$ of hexane. Tricosanoate (Sigma, Saint-Quentin Fallavier, France) was used as the internal standard. Samples were injected by autosampler into a Varian CP-3800 gas chromatograph equipped with a flame ionization detector (Varian, Les Ulis, France). Methyl esters from all samples were separated on a $100-\mathrm{m} \times 0.25-\mathrm{mm}$ i.d. fusedsilica capillary column (CP-Sil 88; Chrompack, Middelburg, The Netherlands). A custom preparation (kindly donated by J. H. Herbein, Virginia Tech), thoroughly described in Loor and Herbein (2003), made with pure methyl esters was used for identification of trans-18:1, nonconjugated 18:2, and CLA isomers primarily. Odd and branched-chain fatty acids and 21:0 were identified with a commercial mixture containing 37 fatty acids (cat\#47885-U; Supelco, Bellefonte, PA). Linolenic acid isomers were identified by comparison with a commercial mixture (cat\# L6032; Sigma). Trans10-18:1, trans 1618:1, trans8,cis 13-18:2, cis9,trans 13-18:2, and trans11,cis15-18:2 were not available commercially. The trans-18:1 isomers were identified by order of elution as described in Griinari et al. (1998), and the 18:2 isomers according to Ulberth and Henninger (1994).

For hay, soybean meal, linseed oil, concentrate mixture, feces, and duodenal fatty acid analysis ( 0.5 to $1 \mu \mathrm{L}$ methyl esters in hexane injected at a 50:1 to $120: 1$ split ratio), the injector temperature was maintained at $250^{\circ} \mathrm{C}$, and the detector temperature was maintained at $255^{\circ} \mathrm{C}$. The initial oven temperature was held at $70^{\circ} \mathrm{C}$ for $1 \mathrm{~min}$, increased $5^{\circ} \mathrm{C} / \mathrm{min}$ to $100^{\circ} \mathrm{C}$ (held for $2 \mathrm{~min}$ ), then increased at $10^{\circ} \mathrm{C} / \mathrm{min}$ to $175^{\circ} \mathrm{C}$ (held for $40 \mathrm{~min}$ ), and $5^{\circ} \mathrm{C} / \mathrm{min}$ to a final temperature of $225^{\circ} \mathrm{C}$ (held for $15 \mathrm{~min}$ ) (as described originally by Loor and Herbein [2001]). Hydrogen was the carrier gas. Injector pressure was held constant at $158.6 \mathrm{kPa}$. We found no advantage in conducting various runs at different isothermal temperatures to separate 18:1 isomers, which is often needed because of the similar equivalent chain length value for certain isomers (Kramer et al., 2001). In our experience (also Loor and Herbein, 2001; Loor et al., 2002d; Loor et al., 2003), holding injector pressure constant rather than gas flow (Griinari et al., 1998; Duckett et al., 2002), allows for better peak resolution in the 18:1, 18:2, and CLA region with the column temperature conditions described previously. Figure 1 shows separations of 18:1 and nonconjugated 18:2 isomers during a single chromatographic run. Isomers in the CLA region eluted as shown in Kramer et al. (2001). Elution order between trans10,cis12-18:2 and 21:0, which may co-elute depending on temperature program (Kramer et al., 2001), was verified by comparing chromatograms of duodenal samples vs. those of milk fat obtained from the same cows before and after a 5 -d infusion of $5 \mathrm{~g} / \mathrm{d}$ pure trans10,cis12-18:2 mixture into the duodenum (Loor et al., 2002b).

\section{Statistical Analysis}

Data for fatty acid intake, duodenal fatty acid flow, apparent biohydrogenation, and apparent fatty acid digestibility are reported as least square means \pm SEM. Data were analyzed as a Latin square with factorial arrangement of treatments using the MIXED procedure 

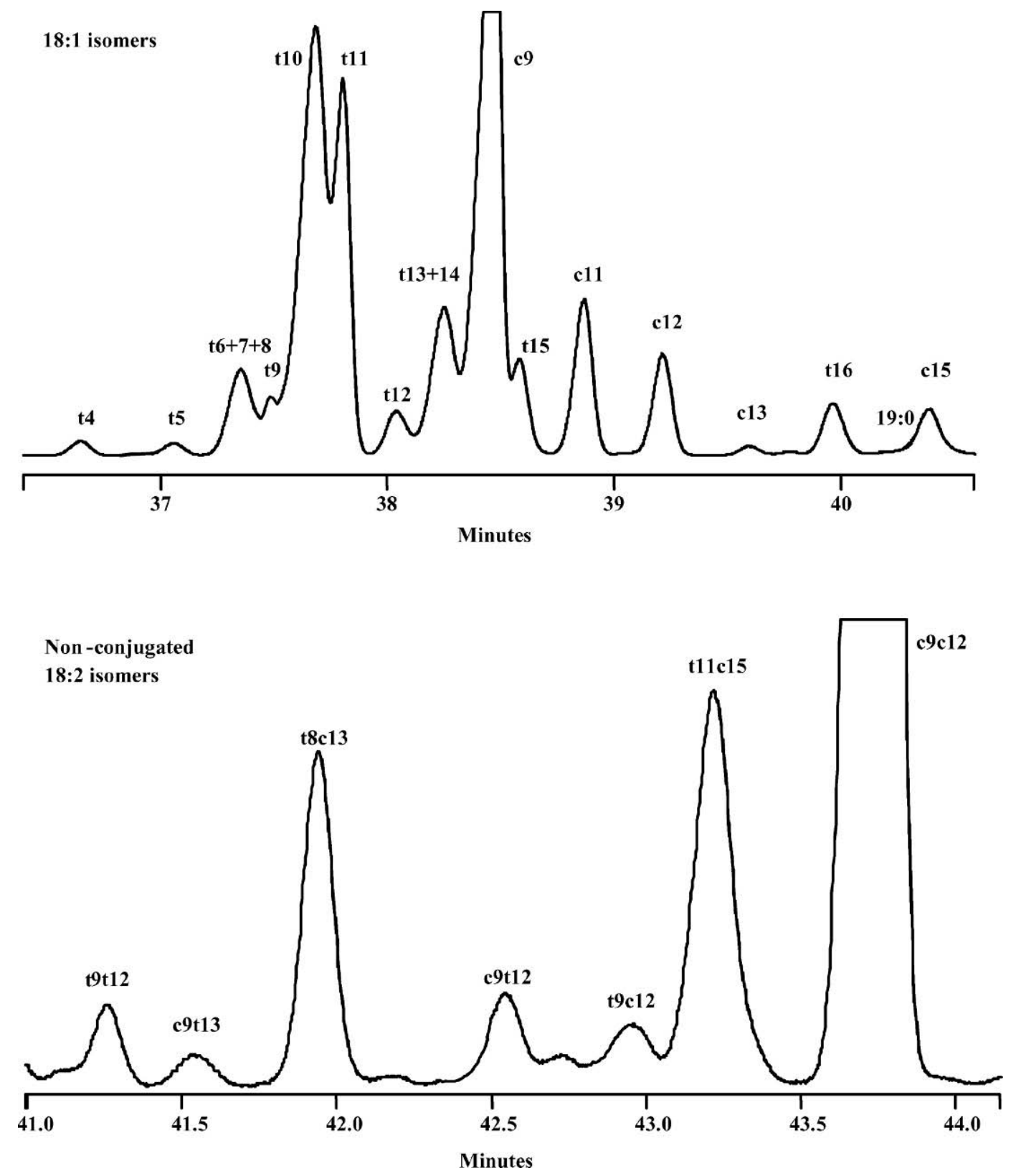

Figure 1. Chromatograms illustrating the separation of cis (c) and trans (t) isomers of 18:1 (high concentrate diet) and nonconjugated 18:2 (high concentrate plus linseed oil) isomers in duodenal digesta samples during a single chromatographic run.

of SAS (SAS Inst., Inc., Cary, NC). The statistical model included cow, period, forage level, oil supplementation level, forage by oil interaction, and residual error. Fixed effects included period, forage level, oil supplementation level, and forage by oil interaction. Cow was the random effect. Overall differences between treatment means were considered to be significant when $P \leq 0.05$. Interactions for level of concentrate and oil were considered significant at $P \leq 0.10$ to guard against Type II error (Berndtson, 1991). This was deemed appropriate be- cause of the low power of the experimental design to test for interactions rather than main effects combined with the a priori expectation for interactions.

\section{RESULTS}

Diets were not markedly different in OM content, but oil-supplemented diets had numerically greater $\mathrm{CP}$ content (Table 1). By design, NDF and ADF concentrations were lower, and starch greater, as level of dietary forage 
Table 2. Fatty acid intake by Holstein cows fed a high or low concentrate diet without supplemental oil (HC, LC) or supplemented at $3 \%$ of DM with linseed oil (HCO, LCO).

\begin{tabular}{|c|c|c|c|c|c|c|c|c|}
\hline \multirow[b]{2}{*}{ Fatty acid, g/d } & \multicolumn{4}{|c|}{ Diet } & \multirow[b]{2}{*}{ SEM } & \multicolumn{3}{|c|}{ Effect $(P=)^{1}$} \\
\hline & $\mathrm{LC}$ & LCO & $\mathrm{HC}$ & $\mathrm{HCO}$ & & Conc & Oil & Conc $\times$ Oil \\
\hline $12: 0$ & 0.73 & 0.66 & 0.45 & 0.42 & 0.07 & 0.01 & 0.46 & 0.78 \\
\hline 14:0 & 2.04 & 2.17 & 1.50 & 1.77 & 0.17 & 0.01 & 0.26 & 0.70 \\
\hline $16: 0$ & 68.6 & 97.3 & 70.3 & 105.0 & 3.93 & 0.24 & 0.01 & 0.44 \\
\hline cis9-16:1 & 2.07 & 2.09 & 2.30 & 2.55 & 0.12 & 0.01 & 0.24 & 0.32 \\
\hline 18:0 & 7.68 & 30.8 & 8.12 & 32.7 & 0.59 & 0.07 & 0.01 & 0.23 \\
\hline cis9-18:1 & 56.4 & 139.1 & 114.9 & 214.0 & 4.75 & 0.01 & 0.01 & 0.11 \\
\hline $18: 2 n-6$ & 96.7 & 180.9 & 142.2 & 238.7 & 5.71 & 0.01 & 0.01 & 0.30 \\
\hline $18: 3 n-3$ & 82.1 & 444.9 & 54.7 & 442.7 & 7.22 & 0.05 & 0.01 & 0.20 \\
\hline Total & 316.4 & 897.8 & 394.6 & 1037.8 & 20.8 & 0.01 & 0.01 & 0.17 \\
\hline
\end{tabular}

${ }^{1} P$ value for the effect of concentrate level (Conc), oil, and the interaction of concentrate and oil.

decreased. Total fatty acid content of low and high concentrate diets alone averaged $1.7 \%$ compared with $4.9 \%$ when linseed oil was added.

\section{Fatty Acid Intake}

Feeding high concentrate diets increased $(P<0.05)$ total fatty acid intake by $109 \mathrm{~g} / \mathrm{d}$ (Table 2). Oleic and linoleic acid intakes also were greater $(P<0.05)$ in response to high concentrate diets. Linolenic acid intake was lower $(-29.6 \mathrm{~g} / \mathrm{d} ; P<0.05)$ with $\mathrm{HC}$ vs. LC, but increased by $375 \mathrm{~g} / \mathrm{d}$ in response to linseed oil.

\section{Duodenal Fatty Acid Flow and Biohydrogenation}

Total fatty acids. Feeding high concentrate diets resulted in an additional flow of $153 \mathrm{~g}$ fatty acids/d (Table 3). Linseed oil increased total duodenal fatty acid flow by $473 \mathrm{~g} / \mathrm{d}$. Net flow (intake - duodenal flow) of fatty acids was $44 \mathrm{~g} / \mathrm{d}$ greater with high concentrate diets and $140 \mathrm{~g} / \mathrm{d}$ greater with linseed oil.

18:3 isomers. Cis 9 ,cis 12 ,cis $15-18: 3$ was the only 18:3 isomer provided in the diet (Table 2), but it accounted for $93 \%$ of total 18:3 isomers in duodenal lipids (Table 4). Its flow was not altered by concentrate level, but feeding $\mathrm{HCO}$ resulted in an increase (significant interaction, $P=0.06)$ of $20.1 \mathrm{~g} / \mathrm{d}$. Feeding low concentrate diets and addition of oil led to greater $(P \leq 0.05)$ flows of cis 9 ,trans 12 ,cis 15-18:3 and cis9,trans 12 ,trans $15-18: 3$. Linseed oil supplementation enhanced flow of trans9,trans 12,trans 15-18:3. We could not identify the presence of cis9,trans11,cis15-18:3 in duodenal lipids because of lack of a standard.

Conjugated 18:2 isomers. Cis9,trans11-CLA flow averaged $0.31 \mathrm{~g} / \mathrm{d}$ with LC or HC (16\% of total CLA flow). Trans10,cis12-CLA was not altered by concentrate or linseed oil level and averaged $0.08 \mathrm{~g} / \mathrm{d}$ (3\% of total CLA flow). Flow of trans9, cis11-, trans8,cis10-, cis 10,trans12-, and cis11,trans13-CLA decreased with LCO but in- creased with HCO $(P<0.05)$. Trans11,cis13- + cis9,cis11-, trans,trans-, and total CLA isomer flow was greater with linseed oil addition. Regardless of concentrate or oil level trans,trans-CLA were the most abundant isomers, followed by cis9,trans11-CLA, and trans11,trans13-CLA. Feeding linseed oil, regardless of concentrate level, increased $(P<0.05)$ flows of cis9,trans11-, trans11,cis13-, trans11,trans13-, and trans, trans-CLA. In terms of absolute amounts, our values are consistent with those obtained by Piperova et al. (2002) with $\mathrm{Ag}^{+}-\mathrm{HPLC}$, which showed for the first time that total conjugated trans,trans-18:2 are the most predominant isomers flowing into the small intestine of dairy cows.

Nonconjugated 18:2 isomers. Cis9,cis12-18:2 flow was $19 \mathrm{~g} / \mathrm{d}$ greater in response to high concentrate diets (Table 4). Linoleic acid accounted for 35 to $84 \%$ of total nonconjugated 18:2 isomer flow depending on diet. Trans9,cis12- and cis9,trans13-18:2 flow was greater $(P$ $<0.05)$ with high concentrate diets and increased $(P<$ 0.05 ) further with linseed oil. These 2 isomers accounted for $<1 \%$ of total nonconjugated 18:2 across diets. Trans11,cis15-18:2 was the second most abundant nonconjugated 18:2 isomer in duodenal lipids, accounting for $4 \%$ of total isomers in response to feeding $\mathrm{LC}$ or HC. Its proportion increased to 28 or 53\% of total nonconjugated 18:2 isomers in cows fed LCO or HCO when flow increased by 9 or $62 \mathrm{~g} / \mathrm{d}$ compared with unsupplemented diets.

Trans-18:1 isomers. Trans11-18:1 flow was not affected by concentrate level but increased $(P<0.05)$ by an average of $76.6 \mathrm{~g} / \mathrm{d}$ with linseed oil supplementation (Table 5). High concentrate diets resulted in a $31-\mathrm{g} / \mathrm{d}$ increase in flow of trans10-18:1. Flows of trans4-, trans6+7+8-, trans13+14-, and trans15-18:1 also were greater $(P<0.05)$ because of the feeding of high concentrate diets. Linseed oil addition further increased flows of trans4- through trans6+7+8- and trans 11 - through trans16-18:1. A major response to linseed oil was a 29- 
Table 3. Duodenal fatty acid flows (not including individual 18:1, 18:2, or 18:3 isomers) in Holstein cows fed a high or low concentrate diet without supplemental oil (HC, LC) or supplemented at $3 \%$ of DM with linseed oil (HCO, LCO).

\begin{tabular}{|c|c|c|c|c|c|c|c|c|}
\hline \multirow[b]{2}{*}{ Fatty acid, g/d } & \multicolumn{4}{|c|}{ Diet } & \multirow[b]{2}{*}{ SEM } & \multicolumn{3}{|c|}{ Effect $(P=)^{1}$} \\
\hline & $\mathrm{LC}$ & LCO & $\mathrm{HC}$ & $\mathrm{HCO}$ & & Conc & Oil & Conc $\times$ Oil \\
\hline $12: 0$ & 1.69 & 2.02 & 1.77 & 2.82 & 0.32 & 0.19 & 0.05 & 0.29 \\
\hline 14:0 & 6.32 & 6.61 & 6.49 & 10.7 & 1.27 & 0.11 & 0.09 & 0.14 \\
\hline iso-14:0 & 1.55 & 1.49 & 1.04 & 1.16 & 0.14 & 0.01 & 0.85 & 0.53 \\
\hline cis $9-14: 1$ & 0.07 & 0.12 & 0.07 & 0.16 & 0.02 & 0.37 & 0.01 & 0.30 \\
\hline $15: 0$ & 9.01 & 11.3 & 6.97 & 9.89 & 0.83 & 0.05 & 0.01 & 0.69 \\
\hline cis $10-15: 1$ & 0.18 & 0.12 & 0.13 & 0.02 & 0.03 & 0.03 & 0.01 & 0.46 \\
\hline iso-15:0 & 11.0 & 12.3 & 10.8 & 13.9 & 1.3 & 0.59 & 0.09 & 0.46 \\
\hline anteiso- $15: 0$ & 10.9 & 14.1 & 11.4 & 12.5 & 1.19 & 0.61 & 0.07 & 0.36 \\
\hline $16: 0$ & 72.2 & 96.9 & 73.5 & 113.6 & 5.8 & 0.14 & 0.01 & 0.19 \\
\hline iso-16:0 & 2.25 & 1.90 & 1.65 & 1.20 & 0.37 & 0.03 & 0.15 & 0.86 \\
\hline trans $9-16: 1+$ iso-17:0 & 2.03 & 2.58 & 1.86 & 2.26 & 0.26 & 0.24 & 0.04 & 0.72 \\
\hline cis9-16:1 & 1.52 & 4.16 & 2.11 & 3.26 & 0.79 & 0.84 & 0.03 & 0.33 \\
\hline $17: 0$ & 3.80 & 4.46 & 3.62 & 4.82 & 0.38 & 0.76 & 0.02 & 0.40 \\
\hline cis $10-17: 1$ & 0.88 & 0.69 & 1.44 & 1.05 & 0.15 & 0.01 & 0.07 & 0.52 \\
\hline $18: 0$ & 196.5 & 454.7 & 201.7 & 313.7 & 41.2 & 0.12 & 0.01 & 0.07 \\
\hline Total odd + branched $^{2}$ & 34.2 & 39.0 & 29.3 & 37.6 & 3.0 & 0.27 & 0.04 & 0.54 \\
\hline Total trans-18:1 & 37.1 & 144.6 & 80.7 & 303.9 & 37.1 & 0.02 & 0.01 & 0.14 \\
\hline Total cis-18:1 & 30.9 & 35.2 & 66.1 & 103.2 & 12.2 & 0.01 & 0.09 & 0.17 \\
\hline Total nonconjugated 18:2 & 26.0 & 34.0 & 43.0 & 120.8 & 22.5 & 0.05 & 0.09 & 0.15 \\
\hline Total conjugated 18:2 & 2.21 & 3.57 & 1.70 & 4.71 & 0.2 & 0.45 & 0.01 & 0.05 \\
\hline Total 18:3 & 9.69 & 15.3 & 9.30 & 31.7 & 5.6 & 0.06 & 0.01 & 0.05 \\
\hline $19: 0$ & 0.53 & 0.67 & 0.38 & 1.12 & 0.14 & 0.30 & 0.01 & 0.05 \\
\hline $20: 0$ & 4.44 & 4.88 & 4.19 & 4.70 & 0.37 & 0.57 & 0.22 & 0.92 \\
\hline cis $11-20: 1$ & 0.53 & 0.48 & 1.46 & 2.26 & 0.41 & 0.01 & 0.36 & 0.30 \\
\hline $21: 0$ & 0.28 & 0.32 & 0.26 & 0.32 & 0.22 & 0.65 & 0.05 & 0.57 \\
\hline Total $^{3}$ & 426.6 & 841.4 & 521.6 & 1052.6 & 57.1 & 0.02 & 0.01 & 0.34 \\
\hline
\end{tabular}

${ }^{1} P$ value for the effect of concentrate level (Conc), oil, and the interaction of concentrate and oil.

${ }^{2}$ Includes fatty acids with 14 - to 19 -carbons.

${ }^{3}$ Total $=$ sum of 12:0 to 21:0 including 18:1, 18:2, and 18:3 isomers.

$\mathrm{g} / \mathrm{d}$ increase in flow of trans $13+14-18: 1$ and an $11-\mathrm{g} / \mathrm{d}$ increase in flow of trans15-18:1. Trans11-18:1 flowing into the duodenum in response to linseed oil accounted for $37 \%$ of total trans-18:1 with LCO and $51 \%$ of total trans-18:1 with HCO. The proportion of trans $13+14-18: 1$ increased from 11 to $17 \%$ of total trans-18:1 with linseed oil addition.

Cis-18:1 isomers. Oleic acid accounted for $69 \%$ of total cis-18:1 flow in response to low concentrate diets, and its proportion decreased to $60 \%$ of total cis-18:1 with high concentrate diets (Table 5). This occurred despite a 28 -g/d increase $(P<0.05)$ in oleic acid flow with high concentrate diets. Increases in flows of cis11-, cis12-, and cis13-18:1 also were associated with feeding high concentrate diets and accounted for the reduced proportion of oleic acid in duodenal lipids. Cis 15-18:1 flow increased more markedly with HCO vs. LCO $(P<0.05)$. Linseed oil supplementation did not affect oleic acid flow. Isomers that responded to linseed oil included cis12- and cis13-18:1.

Odd-chain, branched-chain, and medium-chain monounsaturated fatty acids. Although total flow of odd- plus branched-chain fatty acids did not differ because of concentrate level $(32 \mathrm{~g} / \mathrm{d})$, there were differences in flows among some of these microbial-derived fatty acids (Table 3). Flows of iso-14:0, 15:0, cis10-15:1, and iso-16:0 were greater $(P<0.05)$ in cows fed low concentrate diets; whereas, flows of cis10-17:1 and cis11-20:1 were greater $(P<0.05)$ because of the feeding of high concentrate diets. Linseed oil supplementation resulted in an average increase $(P<0.05)$ of $7 \mathrm{~g} / \mathrm{d}$ in the flow of odd- plus branched-chain fatty acids. This response was related to significantly greater $(P<0.05)$ flows of $15: 0$, 17:0, and 19:0 but also a tendency $(P=0.07)$ for greater flow of anteiso-15:0. Although not a major fatty acid in duodenal lipids, cis10-15:1 flow was reduced $(P<0.05)$ by feeding linseed oil. Supplemental linseed oil increased $(P<0.05)$ flows of cis9-14:1, trans9-16:1 + iso-17:0, and cis9-16:1.

\section{Apparent ruminal biohydrogenation,} stearic acid flow, and flow of total

biohydrogenation intermediates. Ruminal biohydrogenation was estimated as the disappearance of dietary oleic, linoleic, or linolenic acid between mouth and duodenum (Table 6). As suggested by elevated flows of biohydrogenation intermediates and similar flows of 18:0 (Table 3), feeding high concentrate diets decreased biohydrogenation of linoleic and linolenic acid (Table 6). 
Table 4. Duodenal flow of 18:2 and 18:3 isomers in Holstein cows fed a high or low concentrate diet without supplemental oil (HC, LC) or supplemented at 3\% of DM with linseed oil (HCO, LCO).

\begin{tabular}{|c|c|c|c|c|c|c|c|c|}
\hline \multirow[b]{2}{*}{ Isomer, $\mathrm{g} / \mathrm{d}$} & \multicolumn{4}{|c|}{ Diet } & \multirow[b]{2}{*}{ SEM } & \multicolumn{3}{|c|}{ Effect $(P=)^{1}$} \\
\hline & $\mathrm{LC}$ & $\mathrm{LCO}$ & $\mathrm{HC}$ & $\mathrm{HCO}$ & & Conc & Oil & Conc $\times$ Oil \\
\hline \multicolumn{9}{|l|}{$18: 3$} \\
\hline cis $9, \operatorname{cis} 12, \operatorname{cis} 15$ & 8.93 & 12.9 & 8.82 & 29.6 & 4.10 & 0.06 & 0.01 & 0.06 \\
\hline cis $9, \operatorname{trans} 12$, cis 15 & 0.22 & 0.25 & 0.018 & 0.12 & 0.01 & 0.02 & 0.01 & 0.25 \\
\hline cis 9, trans 12, trans 15 & 0.19 & 0.29 & 0.081 & 0.27 & 0.02 & 0.01 & 0.01 & 0.52 \\
\hline trans 9, trans 12, trans 15 & 0.36 & 1.91 & 0.38 & 1.74 & 0.10 & 0.51 & 0.01 & 0.35 \\
\hline \multicolumn{9}{|l|}{ 18:2 conjugated } \\
\hline trans 9, cis 11 & 0.28 & 0.14 & 0.14 & 0.19 & 0.14 & 0.04 & 0.02 & 0.01 \\
\hline trans 8, cis 10 & 0.26 & 0.15 & 0.15 & 0.22 & 0.03 & 0.58 & 0.58 & 0.03 \\
\hline $\operatorname{trans} 10$, cis 12 & 0.08 & 0.07 & 0.07 & 0.10 & 0.01 & 0.45 & 0.56 & 0.14 \\
\hline cis 10, trans 12 & 0.16 & 0.08 & 0.08 & 0.12 & 0.02 & 0.39 & 0.34 & 0.03 \\
\hline cis 11, trans 13 & 0.14 & 0.11 & 0.06 & 0.12 & 0.01 & 0.07 & 0.71 & 0.03 \\
\hline trans $11, c i s 13+\operatorname{cis} 9, \operatorname{cis} 11$ & 0.26 & 0.59 & 0.12 & 0.48 & 0.06 & 0.08 & 0.01 & 0.81 \\
\hline trans 11, trans 13 & 0.33 & 1.34 & 0.22 & 1.37 & 0.16 & 0.75 & 0.01 & 0.57 \\
\hline trans,trans & 0.47 & 0.59 & 0.55 & 1.27 & 0.18 & 0.05 & 0.03 & 0.11 \\
\hline \multicolumn{9}{|l|}{ 18:2 nonconjugated } \\
\hline cis $9, \operatorname{cis} 12$ & 21.8 & 20.2 & 36.5 & 42.8 & 3.95 & 0.01 & 0.52 & 0.29 \\
\hline cis 9, trans 12 & 0.39 & 1.51 & 0.69 & 1.99 & 0.45 & 0.38 & 0.02 & 0.83 \\
\hline trans $8, \operatorname{cis} 13$ & 2.12 & 1.52 & 2.80 & 1.57 & 0.50 & 0.44 & 0.07 & 0.50 \\
\hline trans 9, cis 12 & 0.04 & 0.56 & 0.38 & 3.93 & 0.91 & 0.05 & 0.04 & 0.11 \\
\hline cis 9, trans 13 & $\ldots{ }^{2}$ & 0.63 & 0.22 & 2.39 & 0.45 & 0.05 & 0.01 & 0.12 \\
\hline trans 9, trans 12 & 0.37 & 0.16 & 0.37 & 4.06 & 1.45 & 0.18 & 0.23 & 0.18 \\
\hline trans $11, c i s 15$ & 0.99 & 9.47 & 2.11 & 64.1 & 13.8 & 0.10 & 0.05 & 0.13 \\
\hline
\end{tabular}

${ }^{1} P$ value for the effect of concentrate level (Conc), oil, and the interaction of concentrate and oil.

${ }^{2}$ Isomer not detected in duodenal lipids.

Linseed oil supplementation, however, led to greater biohydrogenation of oleic, linoleic, and linolenic acid in the rumen.

Stearic acid flow, the major end product of biohydrogenation, increased by $112 \mathrm{~g} / \mathrm{d}(\mathrm{HCO})$ to $258 \mathrm{~g} / \mathrm{d}$ (LCO) in response to linseed oil $(P=0.07)$ (Table 3$)$. Flows of trans-18:1, cis-18:1, and nonconjugated 18:2 isomers were 101,52 , and $52 \mathrm{~g} / \mathrm{d}$ greater $(P \leq 0.05)$ in response to high concentrate diets. Total ruminal CLA and 18:3 isomer output increased primarily with $\mathrm{HCO}(P=0.05)$.

Table 5. Duodenal 18:1 isomer flow in Holstein cows fed a high or low concentrate diet without supplemental oil (HC, LC) or supplemented at $3 \%$ of DM with linseed oil (HCO, LCO).

\begin{tabular}{|c|c|c|c|c|c|c|c|c|}
\hline \multirow[b]{2}{*}{ Isomer, $\mathrm{g} / \mathrm{d}$} & \multicolumn{4}{|c|}{ Diet } & \multirow[b]{2}{*}{ SEM } & \multicolumn{3}{|c|}{ Effect $(P=)^{1}$} \\
\hline & $\mathrm{LC}$ & $\mathrm{LCO}$ & $\mathrm{HC}$ & $\mathrm{HCO}$ & & Conc & Oil & Conc $\times$ Oil \\
\hline \multicolumn{9}{|l|}{$18: 1$ trans } \\
\hline 4 & 0.37 & 1.06 & 0.88 & 1.87 & 0.21 & 0.01 & 0.01 & 0.47 \\
\hline 5 & 1.29 & 3.12 & 1.81 & 3.36 & 0.19 & 0.07 & 0.01 & 0.47 \\
\hline $6+7+8$ & 1.83 & 6.75 & 5.98 & 16.2 & 2.48 & 0.02 & 0.01 & 0.27 \\
\hline 9 & 1.38 & 3.89 & 2.96 & 13.1 & 3.30 & 0.12 & 0.08 & 0.26 \\
\hline 10 & 1.46 & 6.61 & 20.2 & 50.6 & 12.1 & 0.04 & 0.20 & 0.38 \\
\hline 11 & 21.4 & 61.7 & 26.0 & 138.8 & 17.2 & 0.10 & 0.01 & 0.17 \\
\hline 12 & 1.93 & 8.32 & 3.78 & 9.57 & 1.24 & 0.21 & 0.01 & 0.81 \\
\hline $13+14$ & 4.17 & 29.6 & 10.3 & 42.9 & 2.75 & 0.01 & 0.01 & 0.19 \\
\hline 15 & 1.95 & 12.1 & 4.84 & 16.8 & 1.52 & 0.02 & 0.01 & 0.56 \\
\hline 16 & 2.34 & 11.5 & 3.98 & 10.7 & 1.39 & 0.75 & 0.01 & 0.39 \\
\hline \multicolumn{9}{|l|}{$18: 1$ cis } \\
\hline 9 & 24.0 & 21.6 & 47.1 & 54.9 & 9.0 & 0.01 & 0.73 & 0.51 \\
\hline 11 & 5.20 & 4.80 & 11.1 & 18.7 & 2.43 & 0.01 & 0.13 & 0.10 \\
\hline 12 & 1.17 & 3.35 & 4.70 & 10.5 & 1.79 & 0.01 & 0.03 & 0.28 \\
\hline 13 & 0.35 & 0.81 & 0.57 & 1.54 & 0.18 & 0.02 & 0.01 & 0.18 \\
\hline 15 & 0.60 & 4.65 & 2.61 & 17.6 & 2.23 & 0.01 & 0.01 & 0.02 \\
\hline
\end{tabular}

${ }^{1} P$ value for the effect of concentrate level (Conc), oil, and the interaction of concentrate and oil. 
Table 6. Biohydrogenation ${ }^{1}$ of unsaturated fatty acids in the rumen of Holstein cows fed a high or low concentrate diet without supplemental oil (HC, LC) or supplemented at 3\% of DM with linseed oil (HCO, $\mathrm{LCO})$.

\begin{tabular}{|c|c|c|c|c|c|c|c|c|}
\hline \multirow[b]{2}{*}{ Fatty acid, \% } & \multicolumn{4}{|c|}{ Diet } & \multirow[b]{2}{*}{ SEM } & \multicolumn{3}{|c|}{ Effect $(P=)^{2}$} \\
\hline & $\mathrm{LC}$ & $\mathrm{LCO}$ & $\mathrm{HC}$ & $\mathrm{HCO}$ & & Conc & Oil & Conc $\times$ Oil \\
\hline cis $9-18: 1$ & 57.9 & 84.5 & 59.6 & 74.3 & 5.5 & 0.30 & 0.01 & 0.15 \\
\hline $18: 2 n-6$ & 77.7 & 88.8 & 74.5 & 82.0 & 1.7 & 0.01 & 0.01 & 0.28 \\
\hline $18: 3 n-3$ & 89.9 & 97.1 & 83.9 & 93.2 & 1.7 & 0.01 & 0.01 & 0.49 \\
\hline Total & 77.3 & 92.9 & 70.7 & 85.7 & 2.1 & 0.01 & 0.01 & 0.89 \\
\hline
\end{tabular}

${ }^{1}$ Biohydrogenation $(\%)=[($ intake of fatty acid - duodenal flow of fatty acid $) /$ intake of fatty acid $] \times 100$.

${ }^{2} P$ value for the effect of concentrate level (Conc), oil, and the interaction of concentrate and oil.

Linseed oil increased $(P<0.05)$ flows of total trans-18:1 and total CLA and tended $(P=0.09)$ to increase total cis-18:1 and total nonconjugated 18:2 isomers.

\section{Apparent Intestinal Digestibility of Fatty Acids}

Nonconjugated 18:2, conjugated 18:2, and 18:3 isomers. Apparent intestinal digestibility of cis9,cis 12 ,cis 15-18:3, cis9,trans 12 ,cis $15-18: 3$, cis9,trans 12 ,trans $15-18: 3, \quad$ trans 9 ,trans 12, trans $15-18: 3, \quad$ cis 9 ,trans11-18:2, cis9,cis12-, trans8,cis13-, trans9,cis12-, cis9,trans13-, and trans11,cis15-18:2 was greater $(P<$ 0.05 ) with high concentrate diets (Table 7). Linseed oil supplementation further increased $(P<0.05)$ apparent intestinal digestibility of cis 9 ,cis 12 ,cis $15-18: 3$, trans 9 ,trans 12 ,trans $15-18: 3$, trans 11 , trans $13-18: 2$, trans 11, cis $13-18: 2, \quad$ cis 9 ,trans $12-18: 2, \quad$ trans 9 ,cis $12-$ 18:2, cis9,trans13-18:2, and trans11,cis15-18:2. Cis9,trans11-18:2 apparent intestinal digestibility tended $(P=0.10)$ to increase with linseed oil supplementation.

Trans-18:1 and cis-18:1 isomers. Apparent intestinal digestibility of all trans-18:1 isomers, except trans418:1 (74\%), without linseed oil supplementation was between 82 and $95 \%$ (Table 8). Dietary concentrate level affected apparent digestibility of only trans4-18:1 and trans12-18:1, which were greater $(P<0.05)$ in response

Table 7. Apparent intestinal digestibility ${ }^{1}$ of 18:2 and 18:3 isomers in Holstein cows fed a high or low concentrate diet without supplemental oil (HC, LC) or supplemented at 3\% of DM with linseed oil (HCO, $\mathrm{LCO})$.

\begin{tabular}{|c|c|c|c|c|c|c|c|c|}
\hline \multirow[b]{2}{*}{ Isomer, \% } & \multicolumn{4}{|c|}{ Diet } & \multirow[b]{2}{*}{ SEM } & \multicolumn{3}{|c|}{ Effect $(P=)^{2}$} \\
\hline & $\mathrm{LC}$ & LCO & $\mathrm{HC}$ & $\mathrm{HCO}$ & & Conc & Oil & Conc $\times$ Oil \\
\hline \multicolumn{9}{|l|}{$18: 3$} \\
\hline cis $9, \operatorname{cis} 12, \operatorname{cis} 15$ & 76.2 & 81.1 & 82.1 & 91.9 & 1.5 & 0.01 & 0.01 & 0.14 \\
\hline cis 9, trans 12, cis 15 & 70.2 & 76.4 & 100 & 100 & 3.8 & 0.01 & 0.45 & 0.86 \\
\hline cis 9, trans, 12, trans 15 & 73.4 & 77.8 & 100 & 81.3 & 4.6 & 0.01 & 0.57 & 0.21 \\
\hline trans 9 ,trans 12, trans 15 & 71.2 & 85.0 & 81.2 & 93.5 & 2.3 & 0.01 & 0.02 & 0.26 \\
\hline \multicolumn{9}{|l|}{ 18:2 conjugated } \\
\hline cis 9, trans 11 & 32.3 & 40.5 & 55.0 & 69.3 & 6.7 & 0.01 & 0.10 & 0.62 \\
\hline trans 9, cis 11 & 80.5 & 73.6 & 77.3 & 80.0 & 8.6 & 0.82 & 0.76 & 0.51 \\
\hline trans $8, \operatorname{cis} 10$ & 80.8 & 73.3 & 74.1 & 79.5 & 5.2 & 0.96 & 0.85 & 0.24 \\
\hline trans 10, cis 12 & $100^{3}$ & 100 & 100 & 100 & $\ldots$ & $\ldots$ & $\ldots$ & $\ldots$ \\
\hline cis 10, trans 12 & 100 & 100 & 100 & 100 & $\ldots$ & $\ldots$ & $\ldots$ & $\ldots$ \\
\hline cis 11, trans 13 & 100 & 100 & 100 & 100 & $\ldots$ & $\ldots$ & $\ldots$ & \\
\hline $\operatorname{trans} 11, \operatorname{cis} 13+\operatorname{cis} 9, \operatorname{cis} 11$ & 73.4 & 84.3 & 69.1 & 76.3 & 3.4 & 0.11 & 0.03 & 0.61 \\
\hline trans 11, trans 13 & 71.2 & 91.3 & 73.2 & 91.0 & 2.4 & 0.69 & 0.01 & 0.59 \\
\hline trans,trans & 66.7 & 71.3 & 69.8 & 81.5 & 4.0 & 0.12 & 0.07 & 0.38 \\
\hline \multicolumn{9}{|l|}{ 18:2 nonconjugated } \\
\hline cis $9, \operatorname{cis} 12$ & 85.4 & 87.0 & 90.9 & 92.2 & 1.3 & 0.01 & 0.26 & 0.89 \\
\hline cis 9, trans 12 & 72.6 & 86.0 & 78.4 & 85.9 & 2.9 & 0.35 & 0.01 & 0.33 \\
\hline $\operatorname{trans} 8, \operatorname{cis} 13$ & 59.4 & 60.5 & 72.9 & 68.5 & 4.2 & 0.02 & 0.67 & 0.47 \\
\hline trans 9, cis 12 & 55.1 & 88.8 & 85.5 & 94.6 & 1.7 & 0.01 & 0.01 & 0.01 \\
\hline cis 9, trans 13 & $\ldots 4$ & 85.5 & 64.6 & 91.6 & 1.6 & 0.01 & 0.01 & 0.01 \\
\hline trans 9, trans 12 & 91.3 & 66.9 & 88.8 & 89.5 & 5.8 & 0.10 & 0.06 & 0.06 \\
\hline trans $11, c i s 15$ & 69.2 & 92.2 & 77.4 & 95.5 & 1.8 & 0.01 & 0.01 & 0.21 \\
\hline
\end{tabular}

${ }^{1}[(\mathrm{~g} / \mathrm{d}$ of duodenal fatty acid $-\mathrm{g} / \mathrm{d}$ of fecal fatty acid)/g/d of duodenal fatty acid] $\times 100$.

${ }^{2} P$ value for the effect of concentrate level (Conc), oil, and the interaction of concentrate and oil.

${ }^{3}$ Isomer not detected in fecal lipids.

${ }^{4}$ Isomer not detected in duodenal or fecal lipids. 
Table 8. Apparent intestinal digestibility ${ }^{1}$ of $18: 1$ isomers in Holstein cows fed a high or low concentrate diet without supplemental oil (HC, LC) or supplemented at 3\% of DM with linseed oil (HCO, LCO).

\begin{tabular}{|c|c|c|c|c|c|c|c|c|}
\hline \multirow[b]{2}{*}{ Isomer, \% } & \multicolumn{4}{|c|}{ Diet } & \multirow[b]{2}{*}{ SEM } & \multicolumn{3}{|c|}{ Effect $(P=)^{2}$} \\
\hline & $\mathrm{LC}$ & $\mathrm{LCO}$ & $\mathrm{HC}$ & $\mathrm{HCO}$ & & Conc & Oil & Conc $\times$ Oil \\
\hline \multicolumn{9}{|l|}{$18: 1$ trans } \\
\hline 4 & 66.6 & 83.4 & 82.2 & 89.4 & 2.2 & 0.01 & 0.01 & 0.06 \\
\hline 5 & 95.2 & 98.0 & 94.7 & 97.5 & 0.5 & 0.32 & 0.01 & 0.95 \\
\hline $6+7+8$ & 91.2 & 94.0 & 90.8 & 95.5 & 1.1 & 0.68 & 0.01 & 0.46 \\
\hline 9 & 90.0 & 93.7 & 90.1 & 95.3 & 1.1 & 0.44 & 0.01 & 0.52 \\
\hline 10 & 90.5 & 94.2 & 91.5 & 95.2 & 1.4 & 0.50 & 0.03 & 0.96 \\
\hline 11 & 87.9 & 92.9 & 85.0 & 93.3 & 1.3 & 0.36 & 0.01 & 0.22 \\
\hline 12 & 82.0 & 92.4 & 86.7 & 93.8 & 1.2 & 0.03 & 0.01 & 0.20 \\
\hline $13+14$ & 91.5 & 94.0 & 87.6 & 94.1 & 1.4 & 0.21 & 0.01 & 0.16 \\
\hline 15 & 92.7 & 93.3 & 89.1 & 93.0 & 1.8 & 0.29 & 0.23 & 0.37 \\
\hline 16 & 91.1 & 90.7 & 86.2 & 90.6 & 2.3 & 0.31 & 0.41 & 0.34 \\
\hline total & 87.9 & 92.7 & 88.4 & 93.8 & 2.0 & 0.42 & 0.04 & 0.31 \\
\hline \multicolumn{9}{|l|}{ 18:1 cis } \\
\hline 9 & 80.3 & 78.8 & 85.5 & 87.4 & 2.0 & 0.01 & 0.93 & 0.31 \\
\hline 11 & 78.4 & 77.1 & 80.6 & 87.9 & 1.9 & 0.01 & 0.09 & 0.02 \\
\hline 12 & 83.1 & 90.0 & 91.9 & 95.8 & 1.2 & 0.01 & 0.01 & 0.23 \\
\hline 13 & 86.3 & 90.2 & 88.4 & 93.1 & 1.1 & 0.04 & 0.01 & 0.68 \\
\hline 15 & 93.0 & 95.3 & 92.8 & 95.5 & 1.2 & 0.99 & 0.06 & 0.85 \\
\hline total & 84.2 & 86.3 & 87.8 & 91.9 & 1.8 & 0.02 & 0.09 & 0.21 \\
\hline
\end{tabular}

${ }^{1}[(\mathrm{~g} / \mathrm{d}$ of duodenal fatty acid $-\mathrm{g} / \mathrm{d}$ of fecal fatty acid)/g/d of duodenal fatty acid] $\times 100$.

${ }^{2} P$ value for the effect of concentrate level (Conc), oil, and the interaction of concentrate and oil.

to feeding high concentrate diets. Linseed oil supplementation resulted in greater $(P<0.01)$ apparent intestinal digestibility of all trans-18:1, except trans16-18:1, and ranged from 89 to $98 \%$. Apparent intestinal digestibility of cis-18:1 isomers ranged from 77 to $96 \%$. Except for cis 15-18:1, apparent intestinal digestibility of other cis18:1 isomers responded to dietary concentrate level. Apparent intestinal digestibility of cis9-, cis11-, cis $12-$, and cis 13-18:1 was greater $(P<0.05)$ with high concentrate diets. Feeding linseed oil enhanced $(P<0.05)$ apparent intestinal digestibility of cis12- and cis13-18:1 and tended $(P=0.06)$ to enhance cis 15-18:1.

Odd-and branched-chain fatty acids, mediumchain fatty acids, stearic acid, and 20:0. Apparent intestinal digestibilities of $i$ so-14:0, 15:0, 16:0, 17:0, 18:0, 19:0, and 20:0 were greater with HCO vs. LCO $(P \leq 0.10$; Table 9). Supplemental linseed oil increased $(P<0.05)$ apparent intestinal digestibilities of 12:0, iso-15:0, and anteiso-15:0. Apparent intestinal digestibility of 14:0 tended $(P=0.08)$ to be greater with linseed oil supplementation.

\section{DISCUSSION}

\section{Duodenal Flow of Odd-Chain and Branched- Chain Fatty Acids}

Decreased flow of some odd (15:0, cis 10-15:1) and branched-chain (iso-14:0, iso-16:0) fatty acids with the high concentrate diets might have been associated with the prevalence of microbial species that thrive in the rumen when diets of high forage content are fed (Tajima et al., 2001). From a review of the literature, it was shown that dietary fiber content is positively related to percentage of odd-chain and branched-chain fatty acids in ruminal bacteria (Sauvant and Bas, 2001). In the present study, molar proportions of acetate, iso-butyrate, and iso-valerate were lower in ruminal fluid from cows fed high concentrate diets (Ueda et al., 2003). Lower ruminal VFA availability might have been associated with decreased microbial synthesis of fatty acids. Results from the present study confirmed previous evidence, indicating that feeding unsaturated lipids or oils to ruminants very often reduces the percentage of odd-chain and branched fatty acids in duodenal lipids (Pantoja et al., 1996; Sauvant and Bas, 2001). This effect could be related to a direct inhibition of unsaturated fatty acids on microbial fatty acid synthesis, which may result in their reduced flows, or a dilution effect, by greater amounts of other fatty acids.

\section{Biohydrogenation of Cis9-18:1, $18: 2 n-6$, and $18: 3 n-3$}

Lower apparent biohydrogenation of $18: 2 n-6$ in response to feeding high concentrate diets was consistent with its greater flow to the duodenum, as observed by Kalscheur et al. (1997). Despite lower 18:3n-3 biohydrogenation when high concentrate diets were fed, its flow to the duodenum was not enhanced, and this response was similar to that observed by Kalscheur et al. (1997). 
Table 9. Apparent intestinal digestibility ${ }^{1}$ of selected fatty acids (not including individual 18:1, 18:2, or 18:3 isomers) in Holstein cows fed a high or low concentrate diet without supplemental oil (HC, LC) or supplemented at $3 \%$ of DM with linseed oil (HCO, LCO).

\begin{tabular}{|c|c|c|c|c|c|c|c|c|}
\hline \multirow[b]{2}{*}{ Fatty acid, ${ }^{3} \%$} & \multicolumn{4}{|c|}{ Diet } & \multirow[b]{2}{*}{ SEM } & \multicolumn{3}{|c|}{ Effect $(P=)^{2}$} \\
\hline & $\mathrm{LC}$ & $\mathrm{LCO}$ & $\mathrm{HC}$ & $\mathrm{HCO}$ & & Conc & Oil & Conc $\times$ Oil \\
\hline $12: 0$ & 59.4 & 71.7 & 62.4 & 80.7 & 3.3 & 0.11 & 0.01 & 0.40 \\
\hline $14: 0$ & 67.7 & 70.1 & 63.1 & 73.0 & 3.2 & 0.79 & 0.08 & 0.26 \\
\hline iso-14:0 & 63.2 & 65.6 & 49.0 & 63.4 & 3.1 & 0.02 & 0.02 & 0.07 \\
\hline $15: 0$ & 67.6 & 70.9 & 58.9 & 71.6 & 2.5 & 0.15 & 0.01 & 0.10 \\
\hline iso-15:0 & 78.4 & 81.4 & 74.6 & 80.3 & 1.4 & 0.08 & 0.01 & 0.31 \\
\hline anteiso-15:0 & 78.7 & 80.6 & 77.7 & 82.9 & 1.6 & 0.64 & 0.04 & 0.29 \\
\hline $16: 0$ & 77.7 & 81.5 & 73.8 & 84.2 & 1.3 & 0.68 & 0.01 & 0.04 \\
\hline $17: 0$ & 54.6 & 50.7 & 13.4 & 40.5 & 4.3 & 0.01 & 0.01 & 0.01 \\
\hline $18: 0$ & 90.9 & 86.5 & 75.6 & 85.3 & 3.2 & 0.03 & 0.41 & 0.04 \\
\hline 19:0 & 87.0 & 82.3 & 74.7 & 86.9 & 2.6 & 0.18 & 0.19 & 0.01 \\
\hline $20: 0$ & 63.1 & 65.6 & 59.5 & 71.4 & 2.6 & 0.68 & 0.02 & 0.10 \\
\hline cis $11-20: 1$ & 73.3 & 73.8 & 91.7 & 94.2 & 1.9 & 0.01 & 0.33 & 0.52 \\
\hline $21: 0$ & 49.7 & 55.9 & 50.6 & 56.7 & 4.7 & 0.85 & 0.21 & 0.99 \\
\hline Total $^{4}$ & 77.4 & 81.6 & 78.9 & 86.1 & 3.6 & 0.35 & 0.04 & 0.15 \\
\hline
\end{tabular}

${ }^{1}[(\mathrm{~g} / \mathrm{d}$ of duodenal fatty acid $-\mathrm{g} / \mathrm{d}$ of fecal fatty acid)/g/d of duodenal fatty acid] $\times 100$.

${ }^{2} P$ value for the effect of concentrate level (Conc), oil, and the interaction of concentrate and oil.

${ }^{3}$ Fatty acids with negative digestibility are not included.

${ }^{4}$ Total $=$ fatty acids with 12 to 21 carbons including 18:1, 18:2, and 18:3 isomers.

Flows of oleic and linoleic acid were only moderately increased and not statistically significant despite numerically lower biohydrogenation when linseed oil was fed with high concentrate diets. Although 18:3n-3 biohydrogenation increased with linseed oil, the extent of the increase in biohydrogenation was lower (93\% vs. 97\%) with the high concentrate diet, which might have partly accounted for the greater flow of 18:3n-3 with $\mathrm{HCO}$ (+236\%) compared with LCO (+44\%). Feeding a $75 \%$ concentrate diet to lactating cows reduced biohydrogenation of 18:2n-6 and 18:3n-3 but did not affect cis9-18:1 hydrogenation (Kalscheur et al., 1997). In contrast, in ewes fed a constant amount of fatty acids from soybean oil in combination with graded increments (18.4 to $72.9 \%$ ) of dietary forage, biohydrogenation of oleic, linoleic, and linolenic acid increased in proportion with dietary forage (Kucuk et al., 2001).

Results from the present study confirmed those of Kalscheur et al. (1997), indicating that a low F:C alone can reduce rates of biohydrogenation and alter profiles of 18:1, 18:2, and 18:3 intermediates flowing to the small intestine. Data from in vivo (Kalscheur et al., 1997) and in vitro (Van Nevel and Demeyer, 1996) studies suggested that low ruminal $\mathrm{pH}$ reduces rates of ruminal biohydrogenation. In the present study, however, we did not observe an effect of concentrate or linseed oil on ruminal $\mathrm{pH}$, which averaged $6.38 \pm 0.12$ (Ueda et al., 2003). We propose that changes in the extent of biohydrogenation when high concentrate diets are fed may be independent of $\mathrm{pH}$. For example, $\mathrm{pH}$ averaged 5.83 in the study of Kalscheur et al. (1997), but dietary starch was $37 \%$ of DM compared with $23 \%$ of DM in the present study (Table 1). Ruminal biohydrogenation may be sensitive to subtle changes in microbial populations induced by dietary starch content (Latham et al., 1972; Tajima et al., 2001) even if ruminal $\mathrm{pH}$ is not reduced.

\section{Duodenal Flow of CLA Isomers}

Total CLA flow increased by $73 \%$ in dairy cows when dietary concentrate increased from 40 to $75 \%$ of DM (Piperova et al., 2002). Concomitantly, cis9,trans11-18:2 and trans 10,cis 12-18:2 flow increased by 60 and $200 \%$. The proportion of trans10,cis12-18:2 increased from 8 to $14 \%$ of total CLA in response to the $75 \%$ concentrate diet (Piperova et al., 2002). The proportion of cis9,trans 11-18:2 did not change, however, and averaged 30\% of total CLA. A number of trans,trans-18:2 isomers also increased their proportions in duodenal lipids from cows fed the $75 \%$ concentrate diet (Piperova et al., 2002). With the exception of trans 10, cis 12-18:2 flow, results from the present study with the high concentrate diet are similar to those observed by Piperova et al. (2002) despite differences in dietary concentrate level ( $75 \%$ vs. $65 \%)$. Thus, a likely factor contributing to the discrepancy in trans10,cis12-18:2 flow between both studies could be the absolute amount of dietary starch which was higher (40\% vs. 23\%) in the study of Piperova et al. (2002). Starch source in the concentrate (corn grain vs. wheat) and(or) forage(s) (corn plus alfalfa silage vs. grass hay) also may be important in terms of manipulating ruminal environment for trans10,cis12-18:2 production. Forages used by Piperova et al. (2002) clearly provided an addi- 
tional amount of starch compared with grass hay in the present study.

In ewes, duodenal flow of cis9,trans11-18:2 increased, but trans10,cis 12-18:2 decreased in response to graded increments of dietary forage at a constant level ( $7.4 \%$ of diet DM) of supplemental fatty acids from soybean oil (Kucuk et al., 2001). Cis9,trans11-18:2 accounted for 35 to 66\% of total CLA and trans10,cis12-18:2 for 26 to 3\% as dietary forage level increased from 18.4 to $72.9 \%$ of DM (Kucuk et al., 2001). In steers fed a typical finishing diet (78\% corn grain), cis9,trans11-18:2 averaged 29\%, whereas trans 10,cis12-18:2 and trans,trans-18:2 averaged 6 or $41 \%$ of total CLA in duodenal lipids (Duckett et al., 2002). Although addition of $2.4 \%$ corn oil to the diet resulted in greater flows of the 3 CLA isomers, the proportion of trans 10,cis 12-18:2 was 26\% compared with 21 or $37 \%$ for cis9,trans11-18:2 or trans,trans-18:2 (Duckett et al., 2002). Overall, data suggest that CLA profile in ruminal outflow is affected by $\mathrm{F}: \mathrm{C}$, type of unsaturated oil, and their interaction.

To our knowledge, no in vivo experiment has evaluated flows of trans10,cis12-18:2 in response to graded increases of dietary grain or concentrate. Recently, it was demonstrated that replacing incremental portions of orchardgrass or red clover with corn grain in dual-flow continuous culture fermenters resulted in linear increases in the output of trans 10,cis 12-18:2 (but also cis9,-trans11-18:2 and trans,trans-18:2) into effluent (Loor et al., 2003). This result indicates that incremental grain or concentrate have the potential to enhance ruminal production of trans10,cis12-18:2. However, data with ruminants fed high concentrate diets alone show that production of trans10,cis12-18:2 may be highly variable. What seems evident from recent experiments (Piperova et al., 2000; Duckett et al., 2002) is that a supply of high linoleic acid oil along with low dietary F:C has the greatest potential to enhance flow of trans 10,cis12-18:2. In contrast, our results indicate that a supply of high linolenic acid oil should lead to enhanced ruminal production of trans11,cis13-, trans11,trans13-, and trans,trans-18:2.

An important effect associated with feeding the high concentrate diets that has direct repercussions on ruminal biohydrogenation is the potential changes in populations of microorganisms. The ratio of cellulolytic (primarily Butyrivibrio fibrisolvens) to propionogenic, lactogenic, and amylolytic bacteria in the rumen of lactating cows was severely reduced by feeding a high concentrate:low forage diet (80:20) (Latham et al., 1972). Counts of Anaerovibrio lipolytica also decreased markedly because of the feeding of a high concentrate diet (Tajima et al., 2001). In vitro, strains of Megasphaera elsdenii isolated from a dry cow fed a 90\% corn grain diet produced more trans10,cis12-18:2 from pure linoleic acid than controls
(Kim et al., 2002). In the absence of "normal" rates of lipolysis, which may reduce biohydrogenation and increase the level of free linoleic acid in the rumen, there would be a greater opportunity for microorganisms such as Megasphaera elsdenii to isomerize linoleic acid to trans10,cis12-18:2. Such an effect could explain the observed increases in the concentration of this isomer in milk fat from cows fed high concentrate diets (Piperova et al., 2002). Ruminal environment in our study, however, may not have changed sufficiently to enhance growth of bacteria capable of isomerizing linoleic acid to trans10,cis12-18:2. Availability of 18:2n-6 (180 to $240 \mathrm{~g} /$ $\mathrm{d}$, with $50 \%$ derived from grass hay) also may not have been high enough to increase trans10,cis12-18:2 synthesis in the rumen. Alternatively, rapid hydrogenation of trans10,cis12-18:2 to trans10-18:1 (Loor and Herbein, 2001) could have reduced the amount of the CLA and increased trans10-18:1 flowing into the duodenum.

\section{Duodenal Flows of Nonconjugated 18:2 Isomers}

We present the first estimates of trans 11, cis $15-18: 2$ flow to the small intestine in ruminants. Trans 11 ,cis 15 to $18: 2$ was the primary 18:2 produced during hydrogenation of 18:3n-3 in vitro (Kemp et al., 1975), and this was confirmed in the present study. Other cis/trans-18:2 and trans/cis-18:2 isomers identified in duodenal lipids were most likely produced as a result of isomerization of dietary 18:2n-6 (Kemp et al., 1975). Data (Table 6) also suggest that the numerical reduction in 18:2n-6 ( -7 percentage units) and 18:3n-3 (-4 percentage units) biohydrogenation when linseed oil was fed in combination with the high concentrate diet contributed to the accumulation of trans9,cis12-18:2, cis9,trans 13-18:2, trans 9 ,trans 12-18:2, and trans11,cis 15 -18:2 intermediates in the rumen.

\section{Duodenal Flow of Trans-18:1, Cis-18:1, and 18:0}

Responses in trans11-18:1 and trans10-18:1 flow with the high concentrate diets are similar to those observed in cows fed a 75\% concentrate diet (Piperova et al., 2002). As indicated for CLA isomers, starch availability and its effects on buffering capacity and(or) alterations in the microbial ecosystem in the rumen must be linked with a shift in the production of isomers with a trans11- to a trans10- double bond. The trans10-18:1 isomer could arise via hydrogenation of trans 10 ,cis $12-18: 2$, as shown initially by Loor and Herbein (2001), or via isomerization of cis9-18:1 (Mosley et al., 2002). An interesting response to linseed oil regardless of concentrate level was the marked increase in flow of trans $13+14-$, trans $15-$, and cis 15-18:1 to the duodenum. We hypothesize that they might have arisen during biohydrogenation of 18:3n-3. 
Trans13-18:1 might have been an end product of trans11,trans13-18:2 (which increased markedly with linseed oil supplementation) hydrogenation. Trans1518:1 might have accumulated during sequential reductions of trans 9 ,trans 12 ,trans $15-18: 3$, whereas cis 15-18:1 might have accumulated via hydrogenation of trans11,cis15-18:2.

Similar to previous results from Kalscheur et al. (1997), feeding high concentrate diets resulted in greater duodenal flow of cis9-18:1. In both studies, the response might have been partly associated with greater intake of oleic acid and a lack of change in its apparent biohydrogenation. Under those circumstances, greater amounts of oleic acid in the rumen might have resulted in a portion being isomerized to trans4-, trans5-, and trans6+7+8-18:1 as shown in vitro (Mosley et al., 2002). Such a response might account for the greater flow of these trans-18:1 isomers observed in the present study with the high concentrate diets. Several cis-18:1 isomers may be formed during isomerization and hydrogenation of 18:2n-6 or 18:3n-3 (Kemp et al., 1975). Results from the present study confirm the accumulation of various cis-18:1 isomers, particularly cis 15-18:1, during hydrogenation of polyunsaturated fatty acids in vivo.

Despite similar 18:0 flow regardless of concentrate level, the large increase in ruminal outputs of total trans18:1, cis-18:1, and nonconjugated 18:2 isomers (Table 3) with high concentrate diets provides evidence of altered ruminal biohydrogenation. When linseed oil was fed, the extent of the response in 18:0 flow was clearly associated with dietary concentrate level $(P=0.07$ for concentrate by oil interaction). Thus, flow of $18: 0$ was $+131 \%$ greater with LCO compared with $+56 \%$ with HCO. This response seemed to be related with lower hydrogenation of $18: 2 n$ 6 and 18:3n-3 in the oil fraction of the high concentrate diet.

\section{Apparent Intestinal Digestibility of Saturated Fatty Acids}

Similar to our results, apparent intestinal digestibility of 18:0 in dairy cows increased linearly with degree of unsaturation of the lipid supplement, regardless of dietary concentrate level (Pantoja et al., 1996). Palmitic acid digestibility was shown to increase with its greater intake (Weisbjerg et al., 1992) as in the current study. Hindgut synthesis of odd- plus branched-chain fatty acids by microbes or hydrogenation of unsaturated fatty acids would lead to lower apparent digestibility of microbial-derived fatty acids and 18:0.

From an extensive review of the literature, it was concluded that, on average, the digestibility of saturated fatty acids increases moderately with chain length and that unsaturated fatty acids are more digestible than saturated fatty acids (Doreau and Ferlay, 1994; Doreau and Chilliard, 1997). Weisbjerg et al. (1992), however, showed that saturated fatty acid digestibilities in cows fed $500 \mathrm{~g} / \mathrm{d}$ of a palmitic acid-rich fat source was greater compared with feeding the same amount of tallow. Digestibilities decreased as the amount of fat fed increased to $1000 \mathrm{~g} / \mathrm{d}$. Rates of micelle formation and(or) bile production may vary in response to the degree of unsaturation and(or) chain length. Alterations in digestive and(or) absorptive capacities of the small intestine also may affect fatty acid digestion.

\section{Apparent Intestinal Digestibility of 18:1 Isomers}

Biohydrogenation in the hindgut might have resulted in a small underestimation of saturated fatty acid digestibility and an overestimation of unsaturated fatty acid digestibility, because digestibility in the small and large intestine are relatively close (Doreau and Ferlay, 1994). Average values for digestibilities of total trans-18:1 and total cis-18:1 regardless of concentrate level in the present study were 88 and $86 \%$, respectively. Digestibilities of total trans-18:1 and total cis-18:1 isomers in response to feeding linseed oil averaged 93 and 89\%, respectively. Overall, our average digestibility values for total 18:1 are greater than the average digestibility $(85 \%)$ reported from a compilation of literature data by Doreau and Ferlay (1994), but similar to those found more recently with high concentrate diets and(or) different lipid supplements with varying degrees of unsaturation (Kalscheur et al., 1997; Loor et al., 2002c; Scollan et al., 2001). Responses to oilseed supplementation may not be comparable with those for free oils because the seed coat may present an additional obstacle for normal digestion and absorption of fatty acids.

\section{Apparent Intestinal Digestibility of $18: 2$ and $18: 3$ Isomers}

Few data exist regarding digestibility of individual 18:2 or 18:3 isomers. In ewes, $18: 2 n-6$ digestibility decreased linearly in response to gradual increases in dietary forage level (Kucuk et al., 2001). In contrast, 18:3n3 digestibility increased. In the present study, greater digestibilities of $18: 2 n-6$ and 18:3n-3 with the high concentrate diet is in agreement with previous results. This response also applies to trans8,cis13-18:2, trans9, cis1218:2, trans 11 ,cis $15-18: 2$, cis 9 ,trans 11-18:2, and all 18:3 isomers. It is important to note that, similar to results found with sheep (Doreau et al., 2003), overall apparent intestinal digestibility of cis9,trans11-18:2 was very low. With forages, in particular, these values may not be accurate because this CLA isomer (and most other ones) was detected in very low amounts. Net synthesis of this 
CLA in the hindgut from 18:2n-6 also would lead to lower apparent digestibility of this isomer, but this has not been demonstrated experimentally. At least for trans9,cis12-18:2 and trans11,cis15-18:2, higher apparent intestinal digestibility seemed to be associated with greater duodenal flow when the high concentrate diet was fed.

In summary, a low dietary $\mathrm{F}: \mathrm{C}$ should be sufficient to reduce unsaturated fatty acid biohydrogenation and increase trans-18:1 flow into the small intestine. Linseed oil supplementation to high concentrate diets may result in further increases in the duodenal flow of trans-18:1 and certain CLA. Independently of changes in $\mathrm{pH}$, high levels of grain or concentrate in the rumen could induce a shift in the production of trans $11-18: 1$, the major trans18:1 intermediate, to trans 10-18:1. Limitations in 18:2n6 substrate and dietary starch may preclude enhanced ruminal outflow of trans10,cis12-CLA. Input of linolenic acid when hydrogenation is incomplete may result in enhanced ruminal outflow of trans11,cis15-18:2, trans11-18:1, trans13+14-18:1, and trans15-18:1. Cis9,trans11-CLA flow into the small intestine will be enhanced marginally with linseed oil because of its low linoleic acid content. However, linseed oil may increase endogenous synthesis of cis9, trans11-CLA in tissues by enhancing postabsorptive availability of trans11-18:1 (Loor et al., 2002a).

\section{ACKNOWLEDGMENTS}

The authors express their sincere appreciation to A. Ollier and all staff members of Experimental FarmDairy Unit Les Cèdres for care and feeding of the cows, particularly D. Roux and F. Anglard. The technical assistance of J. Chabrot during fatty acid analysis also is highly appreciated. Funding for this study was granted primarily by the European Union (project QLRT-200031423 "Healthy Beef") and the French Ministry of Research (project of the "Aliment Qualité Sécurité" program) and partly by the French Ministry of Agriculture (project of the "Association de Coordination Technique Agricole").

\section{REFERENCES}

Anonymous. 1988. Arrêté du 19 avril 1988 fixant les conditions d'attribution de l'autorisation d'expérimenter. Journal Official de la République Française, 27 avril 1988, pp. 5608-5610.

Berndtson, W. E. 1991. A simple, rapid and reliable method for selecting or assessing the number of replicates for animal experiments. J. Anim. Sci. 69:67-76.

Chilliard, Y., A. Ferlay, R. Mansbridge, and M. Doreau. 2000. Ruminant milk fat plasticity: Nutritional control of saturated, polyunsaturated, trans and conjugated fatty acids. Ann. Zootech. 49:181-205.

Demeyer, D., and M. Doreau. 1999. Targets and procedures for altering ruminant meat and milk lipids. Proc. Nutr. Soc. 58:593-607.

Doreau, M., and Y. Chilliard. 1997. Digestion and metabolism of dietary fat in farm animals. Br. J. Nutr. 78:S15-S35.
Doreau, M., Y. Chilliard, H. Rulquin, and D. I. Demeyer. 1999. Manipulation of milk fat in dairy cows. Page 81 in Recent Advances in Animal Nutrition. P. C. Garnsworthy and J. Wiseman, eds. Nottingham Press, Nottingham, UK.

Doreau, M., and A. Ferlay. 1994. Digestion and utilization of fatty acids by ruminants. Anim. Feed Sci. Technol. 45:379-396.

Doreau, M., K. Ueda, and C. Poncet. 2003. Fatty acid ruminal metabolism and intestinal digestibility in sheep fed rye grass silage and hay. Trop. Subtrop. Agroec. 3:289-293.

Duckett, S., J. G. Andrae, and F. N. Owens. 2002. Effect of high-oil corn or added corn oil on ruminal biohydrogenation of fatty acids and conjugated linoleic acid formation beef steers fed finishing diets. J. Anim. Sci. 80:3353-3360.

Griinari, J. M., D. A. Dwyer, M. A. McGuire, D. E. Bauman, D. L. Palmquist, and K. V. V. Nurmela. 1998. Trans-octadecenoic acids and milk fat depression in lactating cows. J. Dairy Sci. 81:12511261.

Kalscheur, K. F., B. B. Teter, L. S. Piperova, and R. A. Erdman 1997. Effect of dietary forage concentration and buffer addition on duodenal flow of trans-C18:1 fatty acids and milk fat production in dairy cows. J. Dairy Sci. 80:2104-2114.

Kemp, P., R. W. White, and D. J. Lander. 1975. The hydrogenation of unsaturated fatty acids by five bacterial isolates from the sheep rumen, including a new species. J. Gen. Microbiol. 90:100-114.

Kim, Y. J., R. H. Liu, J. L. Rychlik, and J. B. Russell. 2002. The enrichment of a ruminal bacterium (Megasphaera elsdenii YJ-4) that produces the trans-10,cis-12 isomer of conjugated linoleic acid. J. Appl. Microbiol. 92:976-982.

Kramer, J. K. G., C. Cruz-Hernandez, and J. Zhou. 2001. Conjugated linoleic acids and octadecenoic acids: Analysis by GC. Eur. J. Lipid Sci. Technol. 103:594-632.

Kramer, J. K. G., and J. Zhou. 2001. Conjugated linoleic acids and trans octadecenoic acids: Extraction and isolation of lipids. Eur. J. Lipid Sci. Technol. 103:593-600.

Kucuk, O., B. W. Hess, P. A. Ludden, and D. C. Rule. 2001. Effect of forage:concentrate ratio on ruminal digestion and duodenal flow of fatty acids in ewes. J. Anim. Sci. 79:2233-2240.

Latham, M. J., J. E. Storry, and M. E. Sharpe. 1972. Effect of lowroughage diets on the microflora and lipid metabolism in the rumen. Appl. Microbiol. 24:871-877.

Loor, J. J., A. Ferlay, M. Doreau, and Y. Chilliard. 2002a. Conjugated linoleic acids (CLA), trans fatty acids, and lipid content in milk from Holstein cows fed a high- or low-concentrate diet with two levels of linseed oil. J. Dairy Sci. 85(Suppl. 1):1188.

Loor, J. J., A. Ferlay, M. Doreau, and Y. Chilliard. 2002b. Intestinal supply of trans10,cis12-18:2 lowers milk fat output in Holstein cows fed a high- or low-fiber diet with two levels of linseed oil. J. Dairy Sci. 85(Suppl. 1):1189.

Loor, J. J., and J. H. Herbein. 2001. Alterations in blood plasma and milk fatty acid profiles of lactating Holstein cows in response to ruminal infusion of a conjugated linoleic acid mixture. Anim. Res. 50:463-476.

Loor, J. J., and J. H. Herbein. 2003. Reduced fatty acid synthesis and desaturation due to exogenous trans10,cis12-CLA in cows fed oleic or linoleic oil. J. Dairy Sci. 86:1354-1369.

Loor, J. J., J. H. Herbein, and T. C. Jenkins. 2002c. Nutrient digestion, biohydrogenation, and fatty acid profiles in blood plasma and milk fat from lactating Holstein cows fed canola oil or canolamide. Anim. Feed Sci. Technol. 97:65-82.

Loor, J. J., W. H. Hoover, T. K. Miller-Webster, J. H. Herbein, and C. E. Polan. 2003. Biohydrogenation of unsaturated fatty acids in continuous culture fermenters during digestion of orchardgrass or red clover with three levels of ground corn supplementation. J. Anim. Sci. 81:1611-1627.

Loor, J. J., J. H. Herbein, and C. E. Polan. 2002d. trans18:1 and 18:2 isomers in blood plasma and milk fat of grazing cows fed a grain supplement containing solvent-extracted or mechanically extracted soybean meal. J. Dairy Sci. 85:1197-1207.

Mosley, E. E., G. L. Powell, M. B. Riley, and T. C. Jenkins. 2002. Microbial biohydrogenation of oleic acid to trans isomers in vitro. J. Lipid Res. 43:290-296. 
Pantoja, J., J. L. Firkins, M. L. Eastridge, and B. L. Hull. 1996. Fatty acid digestion in lactating dairy cows fed fats varying in degree of saturation and different fiber sources. J. Dairy Sci. 79:575-584.

Park, Y., K. J. Albright, Z. Y. Cai, and M. W. Pariza. 2001. Comparison of methylation procedures for conjugated linoleic acid and artifact formation by commercial (trimethylsilyl) diazomethane. J. Agric. Food Chem. 49:1158-1164.

Piperova, L. S., J. Sampugna, B. B. Teter, K. Kalscheur, M. Yurawecz, Y. Ku, K. Morehouse, and R. A. Erdman. 2002. Duodenal and milk trans octadecenoic acid and conjugated linoleic acid (CLA) isomers indicate postabsorptive synthesis is the predominant source of $c i s 9$ containing CLA in lactating dairy cows. J. Nutr. 132:1235-1241.

Piperova, L. S., B. B. Teter, I. Bruckental, J. Sampugna, S. E. Mills, M. P. Yurawecz, J. Fritsche, K. Ku, and R. A. Erdman. 2000. Mammary lipogenic enzyme activity, trans fatty acids and conjugated linoleic acids are related in lactating dairy cows fed a milk fat-depressing diet. J. Nutr. 130:2568-2574.

Sauvant, D., and P. Bas. 2001. La digestion des lipides chez les ruminants. INRA Prod. Anim. 14:303-310.

Scollan, N. D., M. S. Dhanoa, N. J. Choi, W. J. Maeng, M. Enser, and J. D. Wood. 2001. Biohydrogenation and digestion of long chain fatty acids in steers fed on different sources of lipid. J. Agric. Sci. (Camb.). 136:345-355.

Sukhija, P. S., and D. L. Palmquist. 1988. Rapid method for determination of total fatty acid content and composition of feedstuffs and feces. J. Agric. Food Chem. 36:1202-1206.

Tajima, K., R. I. Aminov, T. Nagamine, H. Matsui, M. Nakamura, and Y. Benno. 2001. Diet-dependent shifts in the bacterial population of the rumen revealed with real-time PCR. Appl. Environ. Microbiol. 67:2766-2774

Ueda, K., A. Ferlay, J. Chabrot, J. J. Loor, Y. Chilliard, and M. Doreau. 2003. Effect of linseed oil supplementation on ruminal digestion in dairy cows fed diets with different forage:concentrate ratios. J. Dairy Sci. 86:3999-4007.

Ulberth, F., and M. Henninger. 1994. Quantitation of trans fatty acids in milk fat using spectroscopic and chromatographic methods. J. Dairy Res. 61:517-527.

Van Nevel, C., and D. Demeyer. 1996. Influence of $\mathrm{pH}$ on lipolysis and biohydrogenation of soybean oil by rumen contents in vitro. Reprod. Nutr. Dev. 36:53-63.

Weisbjerg, M. R., T. Hvelplund, and C. F. Borsting. 1992. Digestibility of fatty acids in the gastrointestinal tract of dairy cows fed with tallow or saturated fats rich in stearic acid or palmitic acid. Acta Agric. Scand., Sect. A. Anim. Sci. 42:115-120. 